\title{
Mandatory Aspect to be Considered in Preparing BEV Policy: Judging from the Evaluation of the Policy Three-in-One Policy and the Odd-Even System by the DKI Jakarta Government
}

\author{
Erna Yuliandari ${ }^{1, *}$, L Padmarini ${ }^{2, *}$ \\ ${ }^{1}$ Faculty of Teacher Training and Education. Sebelas Maret University, Jl. Ir. Sutami No.36, Surakarta, Indonesia. \\ ${ }^{2}$ Faculty of Law, Sebelas Maret University, Jl. Ir. Sutami No.36, Surakarta, Indonesia. \\ *Corresponding author.Email: ernayuliandari@staff.uns.ac.id, lunettapdmr@student.uns.ac.id
}

\begin{abstract}
One of the functions and the government's authority is to pull an arrangement by making decisions. These decisions then become rules that must be obeyed by every citizen. This policy aims as an attempt to resolve a societal problem. The DKI Jakarta Government has implemented various programs for air pollution problems, including three-in-one and the odd-even system. However, this policy has not succeeded in reducing air pollution levels in Jakarta. Thus, the purpose of this study is to find the main factors causing the failure of the implementation of the three-in-one policy and the odd-even system. Following that, the results will be used as a lesson for the new policy plan, which is the use of battery electric vehicles (BEV) by the central government. Consequently, the new policy will achieve effectiveness. That being said, the critical aspects that must be considered in policy plans based on previous policies above are the alignment of society and government, maturity of policy planning, and the availability of resources.
\end{abstract}

Keywords: Policies, Pollutants, Air, Government, Vehicles, Emissions.

\section{INTRODUCTION}

Economic center and government in one area proved that it was not a bright idea. The World Air Quality Report, IQAir, in 2020 stated that Jakarta is the ninthworst capital city in the world in terms of air pollutant levels. Centralized mobility, massive overcrowding, and centralized development illustrate the congestion that gradually causes extreme environmental damage. One of the damage mentioned is the contamination of the air element. The air pollution problem is a severe environmental problem considering how vital air is for humans living. General activities of big cities, such as biomass burning, use of transportation, industrial activities, and wind-blown dust are primary and secondary contributions to air quality degradation. The activity mentioned produce black carbon, classified as a PMcomponent $_{2.5}$, which is microscopic particles of combustion residues from fossil materials, biofuels, or biomass. The standard limit by the World Health Organization is $\mathrm{PM}_{10}$. Thus, the lower rate from $\mathrm{PM}_{10}$ indicates the more polluting it is. The direct impact of $\mathrm{PM}_{2.5}$ on humans is an impairment of heart, such as heart and and lung disease, diabetes, cancer, and also imperfect births on a child, slow-growing lung pulmonary, pneumonia, and stunting. Other hazardous effects that would have a global impact are acid rain and climate change. According to Viral Strategies Data for 2018-2019, gasoline and diesel-fueled vehicles contributed $32 \%-57 \%$ to PM levels 2.5 . Unfortunately, based on data from the Central Statistics Agency, the number of motorized vehicles in DKI Jakarta Province has increased every year starting in 1985. This is supported by the low purchase value of motorized vehicles which seems to motivate people to continue buying motor vehicles. 
To control complex problems and require the involvement of the whole nation, the community needs the role of the government. Sondang P. Siagian suggests that there are three forms of state that provide different roles and functions for the government, namely the political state, legal state, and the welfare state [1]. The form of the welfare state means that the government's task is expanded, namely as a guarantor of general welfare with discretionary power. This discretion by the government is recognized normatively in Indonesia; stated in the Law of the Republic of Indonesia Number 30 of 2014 concerning Government Administration. This means that the government has consequences to ensure the welfare of its people through the authority it has. The task of the government is not only to implement laws in the context of implementing the public interest. In certain conditions, the government must be able to take action to resolve the problems that arise. According to one point in Van Vollenhoven's Residual Theory, the state in carrying out its duties has the function of regelling and politie, namely making regulations and formulating policies. So, the existence of the above theories clarifies the government's responsibility to overcome air pollution by issuing regulations. This fact provides sufficient reason for the PTUN lawsuit phenomenon from the people of Jakarta to the provincial government. DKI Jakarta government officials and the parties that oversee them have recently been widely reported in headlines in various media because they were found guilty of the poor air quality of the capital city. The judge granted part of the lawsuit and stated that the relevant state officials had committed acts against the law. According to the judge, the demands that the DKI Jakarta Provincial Government has to fulfill are to supervise the obedience of everyone regarding the provisions of laws and regulations in the field of controlling air pollution and or the provisions of environmental documents. Rules regarding air pollution have been contained in DKI Jakarta Regional Regulation Number 2 of 2005 concerning Air Pollution Control. In essence, the regional regulation contains an obligation for the government to maintain Jakarta's air quality. Besides that, there have been various other legal products that several government agencies have attempted to tackle the problem of air pollution. However, for some reason, the existing regulations have not been able to help minimize PMlevels 2.5 . For this reason, it is necessary to revise new rules or policies from the government. In essence, the author wants to emphasize the accuracy of the verdict of the PTUN judge regarding the responsibility of the DKI Jakarta Provincial Government for the poor local air quality. So, the provincial government of DKI Jakarta is obliged to immediately take action in the form of policies to overcome the critical atmosphere of pollutants in Jakarta's air.
The most well-known policies that have a vision of reducing vehicle volume in Jakarta are three-in-one policy and the odd-even system. The three-in-one policy is a rule limiting the minimum number of passengers (that is, three passengers) in one four-wheeled vehicle. This policy gave rise to a well-known phenomenon called the three-in-one jockey. The three-in-one jockey is an act of selling illegal services that were rampant in its time. Jockeys will ride vehicles with jockey service users when passing through areas guarded by traffic police to meet the three-passenger requirement. This phenomenon then thwarts the goal of reducing vehicle volume. Instead, a policy was implemented based on Governor Regulation Number 164 of 2016 concerning Traffic Restrictions with an odd-even system. It is called an odd-even system because it is allowed or not permitted to access the road, which is determined from the odd-even number of the last digits of the private vehicle number plate. In addition to aiming to reduce congestion, the government also hopes to shift the use of private vehicles to public transportation, so that air quality will improve. The policy issued in 2016 has proven to produce positive outputs because it is still being implemented and even developed in several other areas outside the Jakarta area. The 2016 evaluation of the odd-even system revealed that the average travel time for access decreased by 20 percent (from 18 minutes to 14.3 minutes), the vehicle speed rate could increase by 22 percent (initially $24.16 \mathrm{~km} /$ hour to 29.56 $\mathrm{km} /$ hour), the volume of vehicles decreased by 15 percent, and the use of public transportation modes increased by 5 percent. However, this policy does not apply to two-wheeled vehicles. Two-wheeled vehicles also produce the same emissions. The results of the logistic regression analysis in the previous odd-even policy research, Putri (2020), also showed the ineffectiveness of the odd-even implementation. People still tend to prefer private vehicles rather than switching to public transportation. This causes the main purpose of the policy as a diversion to public transportation is not fulfilled. The failure to achieve this goal is also directly proportional to the government's expectation in making the odd-even system a way to reduce air pollution. No wonder it has been five years since this policy has been implemented, but significant progress has yet to be felt. The unavailability of public transportation also causes the failure to transfer private vehicles to public transportation. In the last few years (starting in the 2014s), the government has attempted a massive development in the public transportation sector. Such developments include the MRT (Mass Rapid Transit project) and the addition of several trans-Jakarta fleets (busways). In fact, unfortunately some accesses yet be reached by public transportation in Jakarta. Thus, the trip can take longer and also cost more. 
In the last two years, the central government announced its participation in overcoming the problem of air pollution through technological developments. Based on Article 1 paragraph 1 of Presidential Regulation Number 55 of 2019, electric motors are electromechanical equipment that consumes electric power to produce mechanical energy as propulsion. This electrical technology is touted as an environmentally friendly technology because it does not emit carbon emissions. The government's enthusiasm at this time is even at the stage of wanting to make Indonesia a granary for the export of electric vehicles (BEV). The Indonesian government considers it has sufficient resources to support this goal. The proof is that Presidential Regulation Number 55 of 2019 above regulates the Acceleration of the program Battery Electric Vehicle program. Finally, this research was conducted to answer the question of what aspects are important to be considered so that the regulation of electric vehicles (BEV) is effective.

\section{METHODOLOGY}

The process of completing this research used a qualitative approach with a descriptive method. Qualitative study is a research method based on the philosophy of postpositivism, used to examine the condition of natural objects (as opposed to experiments), where the researcher is the key instrument. (Sugiyono, 2011). According to Denzin and Lincoln (1994), qualitative research is research that uses a natural setting to interpret occurring phenomena, and it is carried out by involving various existing methods. While descriptive means that research describes an object, phenomenon, or social setting as outlined in narrative writing.

The data collection technique used in this research is the literature review. In literature review, the researcher gathers various information relevant to the topic in order to address the formulation of the research problem. Sources and information of literature review are obtained through scientific books, scientific essays, research reports, theses and dissertations, regulations, statutes, yearbooks, encyclopedias, and other written sources both printed and other electronic sources.

\section{RESULTS AND DISCUSSION}

\subsection{Supporting Factors for the Success of Policy Implementation}

Since the notion of the actual policy cannot be found in the codification of legislation in Indonesia, the meaning of the policy derived from the opinion of legal experts. The definition of policy intersects with two aspects, namely aspects of goals and choices. This aspect of choice means that discretion is an authority that allows government agencies or officials to make choices in taking legal actions and/or concrete actions within the scope of government actions. Darumurti (2012: 57-58) even though there is choice or freedom, the government must make decisions in the case of a legal vacuum. So, this policy is more intensive and specific than other regulations. After its stipulation, the policy goes through the implementation stage. This stage is important as a determinant of whether a policy can achieve its function (success) or fail.

According to Nugroho (2012: 243), the steps for implementing the policy are:

1. Acceptance of the policy, meaning that the public understands that policy is a "game" for managing the future.

2. Policy adoption, meaning that the public agrees and supports the policy as a "game" for managing the future.

3. Strategic readiness, meaning that the public is ready to participate in the implementation of policies, and bureaucrats are ready to be the main implementers.

The theory above adequately illustrates how important public participation is in determining the success of a policy. Different terms but in the same opinion, Gow and Morss (2010: 59) classify differences in goals between actors as one of the indicators that hinder the implementation of activities. In this context, the actors in question are the community and the government. One of the points in Sunggono's theory (2004: 149) also recognizes support as an important indicator that can hinder the implementation of a public policy. Thus, even though people perceive air pollution as a problem, they may not trust the government's capacity and commitment to regulate by implementing an effective long-term solution (Scartascini and Tommasi, 2010, 2014; Franco Chuaire et al., 2017) [2]. People often think that the majority of policy products on environmental issues produce value for a short time, but require a long-term commitment, and their effectiveness is difficult to observe considering the rules related to natural processes.

In addition, according to Meter and Horn (1975) in Winarno (2016: 142), the factors that influence the success of implementation are:

1. The size and objectives of the policy;

2. Policy resources;

3. Characteristics or characteristics of the implementing agency or agency;

4. Inter-organizational communication related to implementation activities; 


\section{The attitude of the implementers; and}

6. The economic, social, and political environment.

The first and second points of this theory prove that the success factor for implementation comes from the policy product itself. While the fifth point in the theory above strengthens the position of community participation as a supporting factor for the success of policy implementation. Sunggono uses the same language as Gow and Morss in his theoretical studies. According to Sunggono (2004: 149), policy implementation has several inhibiting factors. The first point in Sunggono's version of the inhibiting policy factor is occupied by the content of the policy. According to him, implementation failed because the policy was still unclear. In other words, the objectives are not detailed enough, the means and implementation of priorities or the policy programs are too general or non-existent. According to Sunggono, failure in implementation could also be due to a lack of internal and external provisions in the policies to be implemented. The policy that will be implemented itself can also indicate significant deficiencies. Abidin (2012: 158) agrees with this by including points of weakness in the policy itself as an obstacle to policy implementation.

Next, one of the requirements to implement state policies perfectly according to the implementation theory of Hogwood and Gunn (1978) in Nugroho (2014: $220)$ is the availability of sufficient time and resources. In addition, the necessary mix of resources is available. Resources are also contained in four indicators that influence the success of the policy implementation of the Edward III version (1980) in Winarno (2016: 156), among three others, namely communication, tendencies or dispositions, and bureaucratic structure. According to Edward, resources can determine the success of implementation because resources are the driving source of the implementer. The last explanation of policy content points according to Sunggono's theory (2004: 149) explains that other causes of failure to implement a public policy occur due to deficiencies involving supplementary resources, for example, those involving time, cost, or funds, and labor.

\subsubsection{The harmony between the community and the government: viewed from the three-in-one jockey phenomenon.}

Synchronization between the government and the community requires a sense of trust. A data survey in Mexico City (CMDX) shows how the relationship between trust in the government and the wishes of the community can be seen. For example, Mexico is wellknown as a country that has struggled with continual air pollution since centuries ago, even though the Mexican people are highly conscious of the situation, accounting for 95 percent of the air pollution in their country. Mexico ranks low when it comes to trust in the government. This is caused by authoritarian rule, promises of change that are just wishful thinking, and rampant corruption cases. This distrust is very dangerous because it contradicts with the function of the policy itself.

An Inter-American Development Bank study (2021) illustrates the introduction to its research on tax payments. 3 out of 4 participants are willing to pay additional taxes to solve the problem of air pollution, and this desire increases if there is a sense of trust in the president and non-political institutions such as NGOs (government). The results of the study also state the same thing, that high trust in the government will be in line with the community's willingness to pay tax increases to solve air pollution problems. Furthermore, volunteering to pay is 21 percent higher when individuals have trust in the government than individuals who have no trust in the government. In conclusion, the conditions of government and society that are out of sync cannot solve problems or develop effective problem solutions.

In Jakarta itself, the phenomenon of the three-in-one jockey sufficiently illustrates that in the course of its implementation, government products will not be effective if they are not supported by people's trust. Three-in-one program is one of the applications of management demand transportation belonging to the City of Jakarta. This program was implemented on the capital's main roads, which have high density during peak hours during weekdays. Vehicles that pass the specified road are required to have three or more passengers. Sadly, the response of the people of Jakarta seems to be competing with the government, in terms of creativity, to violate this policy, such as the installation of dark window film in the dark and the emergence of the famous phenomenon of the three-in-one jockey. Unfortunately, although it is considered a violation of the rules, the jockey is proudly turned into a job. Jockey is a term intended for those (individuals) who offer their services to do certain jobs (usually illegal), after which the jockeys receive a reward in the form of wages. The phenomenon of the three-in-one jockey has emerged since the enactment of the Decree of the Governor of the Special Capital Region of Jakarta Number 4104 of 2003 until the three-in one policy was abolished. Jobs as jockeys are in great demand by all walks of life (adults, teenagers, and children). The existence of this jockey phenomenon reduces the purpose of three-in-one policy as it should be. According to the previous theory's description, a lack of synchronization-in this case between the government's desire and the actions of the populace-would result in the failure of problem- 
solving. As a result, the primary cause for the three-inone policy's failure is a misalignment between the community and the government. Therefore, in addition to awareness, the trust of the people of Jakarta in the provincial government must be guaranteed to create the same goal, namely reducing air pollution levels. With this, the probability of policy success will increase.

\subsubsection{Maturity of Policy Planning: viewed from the odd-even system.}

Fadhli and Widodo (2019) on the analysis of congestion reduction based on the odd-even system shows that the reduction in the volume of traffic vehicles decreased to 0.68-0.86 (a measure of Volume Capacity Ratio). However, it should be noted that this decrease in vehicle volume only applies to main roads that adopt the odd-even system. The question is, what about the rest of the access that does not apply to the odd-even system? Thus, Putri's research (2020) can fill this void. Data for 27 percent of the 621 respondents' answers chose the alternative of changing travel routes in response to the odd-even policy. Thus, other alternative roads may be affected by the density. In the preliminary description, there has been a brief description of a research survey that stating that the ineffectiveness of the odd-even system is assessed from the choices of public vehicles due to the odd-even policy. In fact, Putri's research (2020) was carried out in Bekasi, a suburban area of Jakarta. Thus, in order to validate the data, it is required to explain the indicators that become the two regions' similarities. Bekasi and Jakarta face the same problems in terms of mobility, congestion, and population density. In addition, according to Betawi Cultural, Yahya Andi Saputra, the culture of the people of Bekasi is not much different from that of Jakarta, which includes Betawi Malay culture. Another questionnaire output stated that as many as 40 percent of research objects prefer to change schedules, buy vehicles with different plates, make fake number plates, or even change their residence compared to using public transportation modes. The percentage of meeting the objectives of the odd-even system, namely the transition to public transportation modes, did not reach 50 percent (only 33 percent). The government appeared to be less concerned about this impact. Congestion and air pollution remain as they were before. If this is the case, then the vehicle's volume is only "moved" instead of being completed. It can even be said to worsen it because of the emergence of alternatives to buying a second vehicle with a different plate. In addition, the odd-even policy does not apply to two-wheeled vehicles, as the researcher mentioned in the introduction. In fact, according to BPS, in 2020, the number of motorcycles in DKI Jakarta was the highest at $16,141,380$. This creates a lack of clarity of purpose because it is clear that the reduction in the volume of vehicles that the government intends is not only for one area. Thus, the core factor causing the failure of the oddeven system policy is the lack of the policy itself, namely regarding the unclear objectives in this case. Or in other words, the ineffectiveness of the policy is caused by the immaturity of the product policy.

Therefore, the policy on electric vehicles (BEV) indeed must be prepared carefully. The possible negative impacts should not conflict with the objectives. For example, electric vehicles (BEVs) are indeed environmentally friendly because they do not produce carbon black. This can happen because the resource used is electrical energy. However, it is useless if it is the source of electricity (power plant) that uses fossil fuels. Regulations regarding the price and tax of electric vehicles (BEV) must be able to lead local people to choose the use of electric vehicles (BEV) over fossil fuel vehicles. Wish that Indonesia was made as a barn for electric vehicles (BEV) did increase national income through exports. However, the smoke produced by the factory can also cause air pollution. Especially in Jakarta since 2015, the percentage of industrial activities followed by the percentage of motorized vehicles as the largest contributor to air pollution. Therefore, further studies are needed to deal with industrial pollution problems or solutions, making the export of electric vehicles (BEVs) a secondary goal.

\subsubsection{Availability of resources}

The case of unavailability of public transportation affects the failure of the objective of the odd-even system, namely the transition from the use of private vehicles to public transportation. Time-consuming and cost-effective are crucial considerations that are impossible for the people of Jakarta to choose, given their culture and work ethic. This can happen because the number of existing public transportation has not reached all areas. In addition, the number is not yet proportional to the population, so vehicles are quickly filled up and need more time to wait for the next vehicle.

When talking about technology, the availability of these resources is one of the critical pillars. Moreover, the primary resources in the policy on the use of electric vehicles (BEV) are material in the form of the electric vehicle (BEV) itself and a set of electricity to charge it. Without this equipment, the policy cannot be applied at all. This demonstrates the theory that the availability of resources can promote policy implementation. Indonesia, the government claims, currently have sufficient material and human resources to implement the program. 


\section{CONCLUSION}

Air pollution in Jakarta is a severe problem that must be resolved immediately. Various policies such as threein-one and the odd-even system were deployed by the DKI Jakarta provincial government. However, these two policies were ineffective or failed. To that end, the government launched an innovation in the form of an electric vehicle production plan (BEV). It is necessary to evaluate existing policies in order to ensure the seamless implementation of this new policy. This evaluation answers the main question: what is the most significant factor that causes the failure of the air pollution control policies (three-in-one and odd-even system). First, the main factor causing the failure of three-in-one policy is the misalignment between the community and the government. This inconsistency can occur if people do not put their trust in the government. Mass violations of the policy in the form of a three-inone jockey show the misalignment between the government's will and the actions of the people. So, this failure should be a lesson. In addition to increasing awareness (to achieve the same goal), the government must increase trust. Second, the main factor causing the ineffectiveness of the odd-even system is the immaturity of the policy. This is evident from the numerous other impacts that run counter to policy objectives (such as increasing the number of vehicles and congestion in other areas). The lesson to be learned is that the government's policies should be packaged as evenly as possible - whether in terms of prices and taxes, pollutants produced by power plants, or air pollution caused by industries producing electric vehicles (BEV). Third, the availability of resources is essential in implementing policies based on the problem of the inability to transfer the use of private vehicles to public transportation due to the inadequate amount of transportation (both from the inaccessibility of the entire region and the number). The same is the case with the new policy implementation plan (use of electric vehicles/BEV). Without the form of the vehicle, of course, the policy on electric vehicles (BEV) cannot be implemented. The same is true for the new policy implementation plan (electric car/battery-electric vehicle use). Indeed, the electric vehicle (BEV) policy cannot be implemented without vehicle's form. Thus, the community alignment with the government, the maturity of government policy plans, and the availability of resources are the most critical factors that the government must consider when developing policies on the use of electric vehicles (BEV) that are truly effective at reducing pollutant level in the air.

\section{REFERENCES}

[1] Sondang P. Siagian, 2015, "Development Administration", Jakarta: PT. Guning Agung, pp. 101-104.

[2] F. Cafferata, B. Hoffman, and C. Scartascini, How Can We Improve Air Pollution ?: Try Increasing Trust First, IDB Working Paper Series $\mathrm{N}^{\mathrm{o}}$ DOI: $10.18235 / 0003453$

[3] A. Yani, 2018, Indonesian Government System: Approach to Constitutional Theory and Practice of the 1945 Constitution, Indonesian Legislation Journal, vol. 15 (2), 61.

[4] A. Putri, 2020, Analysis of Model Selection of Modes Due to the Planned Implementation of OddEven Scheme in Bekasi City, Journal of Land Transportation Research, Vol. 22(2), 157-169.

[5] A. Kusumaningtyas, E. Aldrian, T. Wati, D. Atmoko, and Sunaryo, 208, The Recent State of Ambient Air Quality in Jakarta, Aerosol and Air Quality Research, 18, 2343-2358, DOI: 10.4209/ carIt.2017.10.0391

[6] ME Fadhli and H. Widodo, 2019, Analysis of Congestion Reduction Based on Odd-Even System, Planners InSight, Vol. 2(2), p. 36-41, DOI: https://doi.org/10.36870/insight.v2i2.136

[7] Deshermansyah, 2016, Evaluation of Air Pollution Control Policies in Efforts to Improve Air Quality in DKI Jakarta, Indonesian Journal of Environmental Education and Management, Vol . 1(1), p.1-21, DOI: https://doi.org/10.21009/IJEEM.011.01

[8] Darumurti, Krishna. 2012. Power of the Government's Director. Bandung: PT. Aditya Bakti.

[9] Nugroho D, Riant. 2012. Public Policy. Jakarta: Gramedia.

[10] Winarno, Budi. 2016. Public Policy in the Globalization Era (Theory, Process, and Comparative Case Studies). Yogyakarta: CAPS (Center Of Academic Publishing Service).

[11] Sunggono, Bambang. 2004. Law and Public Policy. Jakarta: PT. Graphic Ray.

[12] Abidin, Said Zainal. 2012. Public Policy. Jakarta: Salemba Humanika.

[13] Presidential Regulation of the Republic of 
Indonesia Number 55 of 2019 concerning the Acceleration of the Battery Electric Vehicle Program.

[14] BPS data of DKI Jakarta Province for 2018-2020 concerning Number of Motorized Vehicles by Type of Vehicle (units) in DKI Jakarta Province.

[15] U. Hasanah, 2012, Eksploitasi Anak: Studi Kasus Joki Three in One Senayan Jakarta Selatan. Diakses dari: https://repository.uinjkt.ac.id/dspace/bitstream/123 456789/24204/1/uswatun\%20hasanah.pdf pada Selasa, 21 September 2021 pk 21.59

[16] A. Syaefudin, 2019, "Budayawan Betawi Sebut Bekasi dan Depok Layak Gabung Jakarta”, diakses dari https://monitor.co.id/2019/08/24/budayawanbetawi-sebut-bekasi-dan-depok-layak-gabungjakarta/ pada Rabu, 22 September 2021 pk. 07.00 